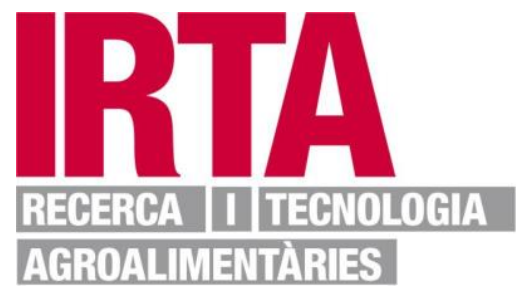

This is an Accepted Manuscript of an article published by Taylor \& Francis in Environmental Technology on 7 September 2018, available online:

https://doi.org/10.1080/09593330.2018.1516802

Document downloaded from:

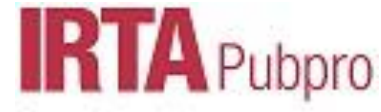

Open dgital archeve 


\title{
Improved anaerobic biodegradability of wheat straw, solid cattle manure and solid slaughterhouse by alkali, ultrasonic and alkali- ultrasonic pre-treatment
}

\author{
Radziah Wahid, Maycoll Romero-Guiza, Verónica Moset, Henrik Bjarne \\ Møller \& Belén Fernández
}

To cite this article: Radziah Wahid, Maycoll Romero-Guiza, Verónica Moset, Henrik Bjarne Møller \& Belén Fernández (2018): Improved anaerobic biodegradability of wheat straw, solid cattle manure and solid slaughterhouse by alkali, ultrasonic and alkali-ultrasonic pre-treatment, Environmental Technology, DOI: 10.1080/09593330.2018.1516802

To link to this article: https://doi.org/10.1080/09593330.2018.1516802

Accepted author version posted online: 28

Aug 2018.

Submit your article to this journal $₫$

View Crossmark data \lceil 
Publisher: Taylor \& Francis \& Informa UK Limited, trading as Taylor \& Francis Group Journal: Environmental Technology

DOI: $10.1080 / 09593330.2018 .1516802$

Improved anaerobic biodegradability of wheat straw, solid cattle manure and solid slaughterhouse by alkali, ultrasonic and alkali-ultrasonic pre-treatment

Radziah Wahid $^{\mathrm{a}, \mathrm{b} *}$, Maycoll Romero-Guiza ${ }^{\mathrm{c}, \mathrm{d}}$, Verónica Moset ${ }^{\mathrm{a}}$, Henrik Bjarne Møller ${ }^{\mathrm{a}}$,

Belén Fernández ${ }^{c^{*}}$

${ }^{a}$ Department of Engineering, Aarhus University, Blichers Allé 20, DK 8830, Tjele, Denmark

${ }^{\mathrm{b}}$ Faculty of Chemistry, Biotechnology, and Food Science, Norwegian University of Life

Sciences (NMBU), P.O. Box 5003, 1432 Ås, Norway

${ }^{\mathrm{c}}$ IRTA, Joint Research Unit IRTA-UPC, Torre Marimon, Road C59- km 12, E 08140 Caldes de Montbui, Barcelona, Spain

d Innovation and Technology Department, FCC Aqualia, Av. Camino Santiago 40, E 28050

Madrid, Spain 
*Corresponding authors:

Radziah Wahid; phone: +4797385504; email: radziah.wahid@nmbu.no

\section{ABSTRACT:}

Wheat straw and animal wastes are important feedstock for biogas production in Europe. Yet, the high content of lignocellulosic and refractory materials causes the process to be relatively slow. Therefore, pretreatment methods have been proposed to shorten the hydrolysis phase. The present study examined the effectiveness of alkali pre-treatment (AP), ultrasonic pre-treatment (UP), and alkali-ultrasonic pre-treatment (AUP) applied on wheat straw (WS), solid fraction of cattle manure (SCM) and solid fraction of slaughterhouse waste (SSHW), by monitoring solubilisation ratio, anaerobic biodegradability and methane yield. The results indicate that the solubilisation ratio of the substrates improved regardless of the types of pre-treatment applied. Though, AP was more effective on WS and SSHW than other pre-treatments (UP and AUP), with approximately $47 \%$ and $17 \%$ extra methane, respectively. Moreover, AP of SCM caused an increased in methane production rate by $100 \%$ and minimised lag phase from 16 days to 1 day during anaerobic digestion. Based on Danish conditions, only AP of WS was economical prior to the biogas process due to high extra methane yield. A positive energy budget of $8 € \mathrm{t}^{-1}$ vs was calculated. High-energy consumption during UP and AUP in laboratory scale hindered the positive benefits of these pre-treatments.

KEYWORDS: Solubilisation ratio; Biodegradability; Modified Gompertz; Energy consumption; Cost-effective 


\section{SYMBOLS AND ABBREVIATIONS:}

\begin{tabular}{|c|c|c|c|}
\hline$\mu_{m}$ & Methane production rate & $\mathrm{KOH}$ & Potassium hydroxide \\
\hline$e$ & Euler's number & WS & Wheat straw \\
\hline$\lambda$ & Lag phase & $\mathrm{CM}$ & Cattle manure \\
\hline$\xi$ & Methane heating value & PS & Pig slurry \\
\hline$\eta$ & $\begin{array}{l}\text { Efficiency energy } \\
\text { conversion }\end{array}$ & SHW & Slaughterhouse was \\
\hline$t$ & Time & $\mathrm{SCM}$ & Solid fraction of cattle manure \\
\hline$P$ & Ultrasonic power & SSHW & $\begin{array}{l}\text { Solid fraction of slaughterhouse } \\
\text { waste }\end{array}$ \\
\hline$V$ & Sample volume & AP & Alkali pre-treatment \\
\hline$T S_{0}$ & $\begin{array}{l}\text { Initial TS concentration of } \\
\text { sample }\end{array}$ & UP & Ultrasonic pre-treatment \\
\hline$\triangle P$ & $\begin{array}{l}\text { Net increase in methane } \\
\text { content }\end{array}$ & AUP & Alkali-ultrasonic pre-treatment \\
\hline $\mathrm{B}_{0}$ & Ultimate methane yield & & Total solid \\
\hline$E_{o} 1$ & $\begin{array}{l}\text { Energy output of } \\
\text { pretreated substrates }\end{array}$ & VS & Volatile solid \\
\hline$E_{o} 2$ & $\begin{array}{l}\text { Energy output of untreate } \\
\text { substrates }\end{array}$ & TAN & Total ammonium nitrogen \\
\hline$E_{\text {process }}$ & $\begin{array}{l}\text { Energy consumption } \\
\text { during pre-treatment }\end{array}$ & VFA & Volatile fatty acids \\
\hline $\mathrm{E}_{\text {in }}$ & Energy input & $\mathrm{t}_{\mathrm{COD}}$ & Total chemical oxygen demand \\
\hline $\mathrm{E}_{\text {out }}$ & Energy output & $\mathrm{s}_{\mathrm{COD}}$ & Soluble chemical oxygen demand \\
\hline & Specific energy demand of & $A B$ & Anaerobic biodegradability \\
\hline$A$ & Initial $t_{\mathrm{COD}}$ converted into & $S$ & Solubilisation ratio \\
\hline & $\begin{array}{l}\text { assay } \\
\text { Initial } t_{\mathrm{COD}} \text { employed in } \\
\text { biomass generation }\end{array}$ & $M$ & $\begin{array}{l}\text { Initial } t_{\mathrm{COD}} \text { converted into methane } \\
\text { at the end of the assay }\end{array}$ \\
\hline
\end{tabular}




\section{INTRODUCTION}

Anaerobic digestion of animal wastes (manure) and by-products (slaughterhouse waste, SHW) offers multiple benefits including improvement of fertilizer quality (digestate), reducing odors and pathogens, and production of biogas [1]. In addition, treating the abovementioned wastes through anaerobic digestion may reduce greenhouse gases (GHG) emissions and minimize leaching of nutrients and organic matter to the environment [1]. However, these wastes often contain recalcitrant materials (e.g. straws or grasses from animal feed, and wood chips or straws from animal bedding) that has a poor biodegradability during anaerobic digestion [2]. To improve the degradability of the materials and increase methane production, pre-treatment is a key step.

Applied pre-treatments alter the properties of lignocelluloses, increasing delignification and solubilisation of hemicelluloses, and promote accessibility of celluloses for enzymatic hydrolysis [3]. Among pre-treatment methods, alkali pre-treatment (AP) is widely investigated because of the efficacy of the treatment to solubilise hemicellulose and lignin [45]. A study by Bruni et al. [6] confirmed that methane yield from digested biofibers was superior when AP was applied on the substrate compared to other methods such as biological, physical, steam and combined pre-treatment. Pre-treatment of biofibers using lime increased methane yield up to $66 \%$. Despite the positive influence of AP, Bruni et al. [6] suggested that for a large-scale implementation, factors such as chemicals cost and the need for extra investment costs for storage tank and mixer should be taken into accounts.

Besides AP, the application of ultrasonic waves on wastewater sludge to improve biogas production is widely known [7], and its application for solid wastes is emerging [8-9]. This technology has already been tested at full-scale system with positive energy balance, meaning there's possibility for large-scale implementation [10]. During ultrasonic pretreatment (UP), the occurrence of acoustic cavitation, disrupt the cell walls of the substrates, 
which increase the specific surface area for enzymatic attack, and reduce the degree of polymerisation [8-9, 11]. Zou et al. [9] reported positive benefits of UP on anaerobic codigestion of maize straw and dairy manure. Approximately $70 \%$ of extra biogas was determined due to the pre-treatment.

Application of combined alkali and ultrasonic pre-treatment for treating lignocellulosic materials have also been reported by previous studies [5,12]. Velmurugan and Muthukumar [5] examined the increase in reducing sugar yield and delignification when alkaline assisted ultrasound pre-treatment was applied on sugarcane bagasse. In addition, Subhedar and Gogate [12] observed a two-fold increase in delignification of waste newspaper when combined pre-treatment was applied compared to alkaline pre-treatment alone

Although some studies on AP, UP and AUP of lignocellulosic materials have been reported [2,5-6,11-12], the knowledge of the above-mentioned pre-treatments for treating WS, solid fraction of cattle manure (SCM) and solid fraction of slaughterhouse waste (SSHW) for biogas production is still scarce. Therefore, the present study aimed to investigate the influence of AP, UP and AUP on selected substrates, through the change of organic matter solubilisation, biodegradability and methane yield, in comparison with non pre-treated substrates. Moreover, this study aimed to evaluate the feasibility of the studied pre-treatments in a biogas plant for the co-digestion of WS with pig slurry (PS), or for the mono-digestion of cattle manure (CM) or slaughterhouse waste (SHW). For that purpose, energy balance and preliminary cost calculation were included.

\section{MATERIAL AND METHODS}

\subsection{Sample collection and preparation}

Cattle manure and WS were collected from a cow farm in Olot, Spain. The CM contained faeces, urine and bedding materials. The SHW consisted of animal blood, stomach 
and intestinal content, and fibre from animal bedding; this waste was collected from a slaughterhouse (Soria, Spain) and sterilised by thermal treatment at $133^{\circ} \mathrm{C}$, following the European Regulation 1069/2009/EC for sanitation purposes. The solid fraction from CM and SHW were obtained through sieving using $1 \mathrm{~mm}$ mesh. The solid and liquid fraction were analyzed for chemical compositions and stored at $4^{\circ} \mathrm{C}$ until further usage. Wheat straw was shredded to a particle size of 1-2 mm using laboratory mincer (Molinex) and stored at room temperature. For batch test purposes, solid fraction from CM and SHW were mixed with the respective liquid fraction while WS was co-digested with pig slurry collected from a pig farm in Barcelona, Spain.

\subsection{Substrate pre-treatments}

Pre-treatments of the substrates were carried out at room temperature $\left(25^{\circ} \mathrm{C}\right)$. Pretreatment conditions such as alkali treatment time and alkali concentration were selected based on our previous work by Moset et al. [13]. Potassium hydroxide (KOH) was selected instead of sodium hydroxide $(\mathrm{NaOH})$ for alkali pre-treatment, because $\mathrm{KOH}$ can be recycled and used as fertilizer [14]. The parameters for ultrasonic pre-treatment were selected based on Subhedar and Gogate [15].

\subsubsection{Ultrasonic pre-treatment}

The UP was performed using a Digital Sonifier Unit Model 250 (Branson Inc. Danbury, CT, USA; maximum output of $200 \mathrm{~W}$ ) and the sonotrode was placed in the middle of a 200 mL beaker. The ultrasonic energy was transmitted directly to the sample for 20 minutes, with an operation pattern of 40 seconds on and 40 seconds off, with $20 \mathrm{kHz}$ and power density of $2 \mathrm{~W} \mathrm{~mL}^{-1}$. The temperature of the samples raised between 30 to $36^{\circ} \mathrm{C}$ (from room temperature, $22-25^{\circ} \mathrm{C}$ ) after sonication. 


\subsubsection{Alkali pre-treatment}

The AP was conducted in a closed container. The solid substrates were soaked with $8 \%$ $\mathrm{KOH}$ (Sigma-Aldrich, Germany) with dilution ratio of 9:1 (water to solid ratio) and stirred manually. The container was closed and kept at room temperature $\left(25^{\circ} \mathrm{C}\right)$ for 24 hours, without any stirring devices.

\subsubsection{Alkali-ultrasonic pre-treatment}

The substrates were firstly treated with AP and then undergone UP. Similar AP and UP procedure were followed as mentioned in section 2.2.1 and 2.2.2. Each pre-treatment were performed in duplicates and the average of two measurement was presented. The pre-treated substrates were analyzed for chemical compositions and were kept at $4^{\circ} \mathrm{C}$ before prepared for batch test.

\subsection{Biochemical methane potential (BMP) test}

Batch test was conducted at mesophilic temperature $\left(35^{\circ} \mathrm{C}\right)$ for 39 days to determine the cumulative methane yield from the substrates, following Angelidaki et al. [16] and Rodriguez-Abalde et al. [17]. The inoculum was collected in a mesophilic digester of an urban wastewater treatment plant (WWTP) in Barcelona, Spain and stored for a week at $35^{\circ} \mathrm{C}$ to ensure the consumption of residual organic matter. The untreated (three samples) and pretreated substrates (nine samples; 3 substrates x 3 pre-treatments) were analyzed in parallel and in duplicates, with the similar inoculum and inoculum to substrate ratio of $1: 1$. The solid fraction from $\mathrm{CM}$ and SHW were mixed with their corresponding liquid fraction and WS was co-digested with PS. The percentage of solid and liquid fraction added to the bottle was based on the ratio of solid to liquid after separation using sieve which was, 27:73 for CM, 14:86 for SHW while for WS, ratio of 50:50 was selected. The substrates, together with inoculum, 
bicarbonate ( $\left.1 \mathrm{~g} \mathrm{~g}^{-1} \mathrm{tCOD}\right)$ and deionized water were weighed and added to $1.2 \mathrm{~L}$ bottles. The $\mathrm{t}_{\mathrm{COD}}$ of the mixture was maintained at $5 \mathrm{~g} \mathrm{~L}^{-1}$ in each bottle. Two blank controls consisted only inoculum were also included.

Methane content in biogas produced was determined using a gas chromatograph CP3800 (Varian, Palo Alto, CA, USA) fitted with Hayesep Q 80/100 Mesh (2m x 1/8" x 2.0 mm SS) packed column (Varian, Palo Alto, CA, USA) and TCD detection. The calculated methane yield was corrected to standard conditions at $273 \mathrm{~K}$ and $1013 \mathrm{hPa}$ and expressed in term of $\mathrm{L} \mathrm{kg}^{-1} \mathrm{COD}$.

\subsection{Analytical methods}

The treated and untreated solid substrates, liquid manure and pig slurry were characterized by their content of total solids (TS) and volatile solids (VS) following APHA [18]. Total volatile fatty acids (VFA) concentration and individual acid profile (acetic, propionic, butyric, and valeric acids) were determined with a CP-3800 gas chromatograph (Varian, Palo Alto, CA, USA), fitted with TRB-FFAP (30 m x $0.32 \mathrm{~mm}$ x $0.25 \mu \mathrm{m}$ ) capillary column (Tecknokroma, Barcelona, Spain) and FID detection. Total chemical oxygen demand $\left(\mathrm{t}_{\mathrm{COD}}\right)$ and soluble chemical oxygen demand $\left(\mathrm{s}_{\mathrm{COD}}\right)$ were measured following method proposed by Noguerol-Arias et al. [19] . The elemental composition (C, H, O and N) was determined by catalytic oxidation, combined with gas chromatography (Elemental Analyser LECO Truspee CHNS, USA). Scanning electron microscope (SEM) analysis of the untreated substrates was performed with Nova Nano SEM 600 (FEI, USA), operated at 15kV, using a low vacuum detector during the analysis. 


\subsection{Mathematical}

Solubilisation ratio (S, \%) was calculated as equation 1, following Jackowiak et al. $[20]$.

$S=\left(s_{C O D} / t_{C O D}\right) \times 100$

Where $\mathrm{s}_{\mathrm{COD}}$ is soluble chemical oxygen demand of the wastes after pre-treatment (solid + liquid fraction) and $t_{\mathrm{COD}}$ is total chemical oxygen demand of the wastes.

Anaerobic biodegradability $\left(A B, \% \mathrm{t}_{\mathrm{COD}}\right)$ was calculated with equation 2 , following Rico et al. [21].

$\% A B=\% M+\% A+\% X$

Where, $\% A B$ is the percentage of anaerobic biodegradability; $\% M$ is the percentage of initial $\mathrm{t}_{\mathrm{COD}}$ converted into methane at the end of the assay; $\% A$ is the percentage of initial $\mathrm{t}_{\mathrm{COD}}$ converted into VFA at the end of the assay; $\% X$ is the percentage of $t_{\mathrm{COD}}$ employed in biomass generation. The details of the equation can be found in Rico et al. [21].

In order to examine the methane yield with different pre-treatments, a non-linear regression was utilised to achieve representative simulations and predictions. The modified Gompertz model (Eq.3) has been used widely by previous researchers in describing and predicting cumulative methane yield through the entire anaerobic digestion [22-24].

$B=B_{0} \cdot \exp \left\{-\exp \left[\mu_{m} \cdot e / B_{0}(\lambda-t)+1\right]\right\}$

Where, $\mu_{m}$ is the methane production rate $\left(\mathrm{L} \mathrm{kg}^{-1} \mathrm{COD} \mathrm{d}^{-1}\right) ; e$ is the Euler's number $(2.7182) ; \lambda$ is the lag phase period (days) or the minimum time required to produce methane. The $B_{0}, \mu_{m}$ and $\lambda$ were predicted using Eq. 3 with the aid of Solver function of the Microsoft Excel Tool Pak. The squared correlation coefficient $\left(\mathrm{R}^{2}\right)$ was used to evaluate the precision of the model fit. The significance difference was statistically analyzed using Tukey test with JMP Pro 13 software. 


\subsection{Energy balance}

To assess the economic feasibility of the pre-treatments, the input $\left(\mathrm{E}_{\mathrm{in}}\right)$ and output energy $\left(E_{\text {out }}\right)$ were calculated and the net energy balance indicates the difference between $E_{\text {in }}$ and $\mathrm{E}_{\text {out }}$.

\subsubsection{Energy input from alkali pre-treatment}

The energy input due to AP was made with an assumption that energy consumption of potassium was $7 \mathrm{MJ} \mathrm{kg}^{-1} \mathrm{~K}$ [25].

\subsubsection{Energy input from ultrasonic pre-treatment}

Energy input during UP was calculated following [26-27], using equation 4.

$E_{U S}=P x t /\left(V x T S_{0}\right)$

(Eq. 4)

Where, $E_{U S}$ is the specific energy demand of sonication $\left(\mathrm{kJ} \mathrm{kg}^{-1} \mathrm{TS}\right) ; P$ is the ultrasonic power $(\mathrm{W}) ; t$ is the ultrasonic treatment time (seconds); $V$ is the sample volume (L); $T S_{0}$ is the initial TS concentration of sample $\left(\mathrm{g}_{\mathrm{TS}} \mathrm{L}^{-1}\right)$.

\subsubsection{Energy output}

Energy output was calculated following Passos et al. [28], expressed by multiplying net increase in methane content $\left(\Delta P ; \mathrm{m}^{3} \mathrm{~g}^{-1} \mathrm{vs}\right)$ with methane heating value $\left(\xi ; 35.8 \mathrm{~kJ} \mathrm{~L}^{-1}\right)$ and efficiency energy conversion $(\eta ; 90)$.

$\mathrm{E}_{\mathrm{o}}=\Delta \mathrm{P} . \xi . \eta$

\subsubsection{Net energy balance}

Net energy balance was expressed following equation 6 .

Net energy gain $=\left(E_{o} 1-E_{o} 2\right)-E_{\text {process }}$ 
Where, $E_{o} l$ and $E_{o} 2$ are the energy output of pretreated and untreated substrates, and $E_{\text {process }}$ is the energy consumption during pre-treatment.

\section{RESULTS AND DISCUSSIONS}

\subsection{Substrates}

The characteristics of untreated WS, PS, CM and SHW are shown in Table 1. As observed, the substrates are different in their chemical characteristics. The carbon to nitrogen ratio of the solid wastes varied from 38 to 46. From the elemental analysis, the organic substrates WS, CM and SHW could be presented as $\mathrm{C}_{79} \mathrm{H}_{98} \mathrm{O}_{52} \mathrm{~N}_{2}, \mathrm{C}_{75} \mathrm{H}_{80} \mathrm{O}_{43} \mathrm{~N}_{2}$ and $\mathrm{C}_{91} \mathrm{H}_{108} \mathrm{O}_{52} \mathrm{~N}_{2}$, respectively. Moreover, $\mathrm{t}_{\mathrm{COD}}$ of WS+PS was higher $\left(554 \mathrm{~g}_{\mathrm{O} 2} \mathrm{~kg}^{-1}\right)$ than $\mathrm{SHW}$ $\left(158 \mathrm{~g}_{\mathrm{O} 2 ~ \mathrm{~kg}^{-1}}\right)$ and $\mathrm{CM}\left(115 \mathrm{~g}_{\mathrm{O} 2} \mathrm{~kg}^{-1}\right)$. The solid content showing highest value for WS (427 $\mathrm{g}_{\mathrm{TS}} \mathrm{kg}^{-1}$ and $396 \mathrm{~g}_{\mathrm{VS}} \mathrm{kg}^{-1}$ ), while the values were comparable for CM and SHW (91 $\mathrm{g}_{\mathrm{TS}} \mathrm{kg}^{-1}$ and $76 \mathrm{~g}_{\mathrm{VS}} \mathrm{kg}^{-1}$ for $\mathrm{CM}$, and $90 \mathrm{~g}_{\mathrm{TS}} \mathrm{kg}^{-1}$ and $80 \mathrm{gVS} \mathrm{kg}^{-1}$ for SHW). The microstructure and morphology of untreated solid wastes were compared by the SEM images (Figure 1). Untreated WS (Figure 1a) exhibited intact structure with a regular texture as compared to SCM (Figure 1b) and SSHW (Figure 1c). The waxes and derivatives were also observed on the surface of WS. In contrast, the surface of solid CM and SSHW were uneven and broken. The broken structure was severe for CM than SSHW and small holes were visible on the surface of CM. The CM is a digested waste while SSHW consisted bedding materials (stepping effects by cow), attributed to uneven and broken structure. The SEM images confirmed the characteristics of WS, CM and SSHW.

\subsection{Solubilisation ratio}

Figure 2 presents solubilisation ratio $\left(\mathrm{s}_{\mathrm{COD}} / \mathrm{t}_{\mathrm{COD}}\right)$ of untreated and pre-treated $\mathrm{WS}, \mathrm{CM}$ and SHW. Regardless the types of pre-treatment, an increased in $\mathrm{s}_{\mathrm{COD}}$ concentration was 
observed after pre-treatment of the substrates. The increment was ranging from 14 to $17 \%$ for WS, 18 to $22 \%$ for solid CM and 16 to $17 \%$ for SSHW. It was observed that solubilisation ratio due to UP was lower compared to AP and AUP when the pre-treatment was applied on WS and solid CM. Similar results was reported by Frigon et al. [29], who observed that the alkali pre-treatment of summer harvest switch grass caused greater influence on $\mathrm{s}_{\mathrm{COD}}$ concentration than sonication pre-treatment. In previous study, the $s_{\mathrm{COD}}$ concentration due to alkali pre-treatment at $35^{\circ} \mathrm{C}$ was increased by 5-fold, from 1.9 to $10.1 \mathrm{~g} \mathrm{~L}^{-1}$, while sonication increased the $\mathrm{S}_{\mathrm{COD}}$ concentration from 0.7 to $4.8 \mathrm{~g} \mathrm{~L}^{-1}$. Solubilisation ratio of pre-treated SSHW was similar regardless pre-treatment applied.

\subsection{Methane yield}

\subsubsection{Methane content}

Methane content per unit percentage measured from the batch bottles were shown in Figure 3a. As observed, substrate types significantly influenced methane content (Figure 3b) and the maximum methane content was observed from SHW, followed by CM and WS+PS. Methane content of SHW varied from $72-73 \%$ while $65-66 \%$ and $58-61 \%$ were observed from $\mathrm{CM}$ and WS $+\mathrm{PS}$, respectively. Pre-treatment methods itself did not influence methane content and comparable values were examined between untreated and pre-treated substrates.

\subsubsection{Cumulative methane yield}

Table 2 presents the cumulative methane yield of the respective substrates at 39 days of anaerobic digestion. The highest methane yield were obtained from WS+PS (203 to $284 \mathrm{~L} \mathrm{~kg}^{-}$ ${ }^{1}$ COD) and SHW (174 to $213 \mathrm{~L} \mathrm{~kg}^{-1} \mathrm{COD}$ ), followed by CM (100 to $122 \mathrm{~L} \mathrm{~kg}^{-1}$ COD). Pretreatment of WS using AP and AUP enhanced methane yield up to 40 and 19\% respectively, while UP of WS did not influence methane yield. Likewise, AP and AUP of SCM increased 
methane yield to $19 \%$ and $12 \%$, and no significant influence of UP on SCM. All pretreatment applied on SSHW increased approximately $22 \%$ of methane yield.

\subsubsection{Modified Gompertz model}

The modified Gompertz model was used in this study to evaluate and compare the pretreatment performance on WS, CM and SHW. The mathematical model parameters were summarized in Table 2 and methane profile based on the model was shown in Figure 4. It can be observed that the modified Gompertz model $\left(\mathrm{R}^{2}>0.97\right)$ can fit the experimental data well. It is noted that pre-treatment of WS and SSHW caused an increased in overall methane yield $\left(\mathrm{B}_{0}\right)$ and did not influence methane production rate $\left(\mu_{\mathrm{m}}\right)$. In contrast, pre-treatment of SCM enhanced methane production rate and reduced lag phase.

The $\mathrm{B}_{0}$ values of untreated and pre-treated WS+PS were ranging from 188 to $277 \mathrm{~L} \mathrm{~kg}^{-}$

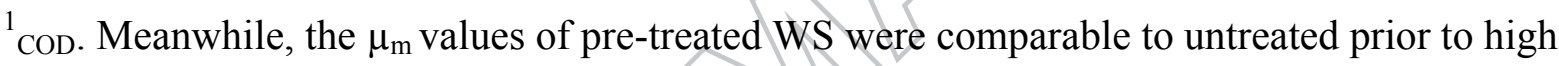
variation among duplicates. The lag phase of untreated WS was 1 day, which was similar as reported by Liu et al. [23]. The short lag phase time may likely due to soluble and easily digestible compound contains in untreated WS and lack of inhibitor [23].

Pre-treatment of SCM using AP and AUP slightly increased $\mathrm{B}_{0}$ values, and significantly enhanced $\mu_{\mathrm{m}}$ to two-fold, from 2 to $4 \mathrm{~L} \mathrm{~kg}^{-1} \mathrm{COD} \mathrm{d}^{-1}$. The $\mathrm{B}_{0}$ values for untreated CM was $118 \mathrm{~L} \mathrm{~kg}^{-1}$ CoD while $\mathrm{B}_{0}$ of pre-treated CM were ranging from 121 to $133 \mathrm{~L} \mathrm{~kg}^{-1} \mathrm{COD}$. Long lag phase of untreated CM was reduced from 16 days to 1 day when AP and AUP were applied. It is noted that UP alone was not an effective on CM.

Regardless the type of pre-treatments applied on SSHW, $\mathrm{B}_{0}$ values were comparable and significantly influenced the untreated sample. The $\mathrm{B}_{0}$ values of pre-treated samples were increased from 168 to 196 (AP), 194 (UP) and $195 \mathrm{~L} \mathrm{~kg}^{-1}$ COD (AUP). Meanwhile, $\mu_{\mathrm{m}}$ and $\lambda$ 
values of pre-treated SSHW were similar to untreated. The $\mu_{\mathrm{m}}$ ranging from 22 to $28 \mathrm{~L} \mathrm{~kg}^{-}$ ${ }^{1} \mathrm{COD}^{-1}$ and $\lambda$ was 2 days.

\subsection{Anaerobic biodegradability}

Table 3 presents the percentage of $A B$ of WS+PS, CM and SHW, which comprises, 1) $M$-percentage of initial $\mathrm{t}_{\mathrm{COD}}$ converted into methane, 2) $A$-percentage of initial $\mathrm{t}_{\mathrm{COD}}$ converted into VFA and 3) $X$-percentage of initial $\mathrm{t}_{\mathrm{COD}}$ used for biomass production. As observed, untreated samples of WS+PS and SHW present similar $A B$ percentage $(57 \%)$, while CM has lower $A B$ value, approximately $35 \%$. It is observed that large fraction of initial $\mathrm{t}_{\mathrm{COD}}$ of untreated WS+PS was converted into methane (54\%), $1 \%$ converted into VFA and $2 \%$ was employed for biomass production. Approximately $47 \%$ of initial $\mathrm{t}_{\mathrm{COD}}$ of untreated SHW was converted into methane, $7 \%$ residual VFA and $3 \%$ was used by anaerobes for biomass production. Regarding untreated CM, only $29^{\circ} \%$ of initial $\mathrm{t}_{\mathrm{COD}}$ was transformed into methane, $4 \%$ residual VFA and $2 \%$ was needed for biomass generation.

Anaerobic degradability of untreated WS was improved up to $42 \%$ by means of AP. It was observed that approximately $77 \%$ of $\mathrm{t}_{\mathrm{COD}}$ was converted into methane and, $1 \%$ of residual VFA and 3\% was used for biomass production. Meanwhile, UP and AUP had no significant influenced on $A B$ of WS. Slight increase in $A B$ of CM was observed when AP and AUP was applied on SCM. The $A B$ of untreated CM rise from $35 \%$ to $39 \%$ (AP) and to $45 \%$ (AUP). All pre-treatment significantly improved $A B$ of SHW and the increment was around 28 to $35 \%$.

\subsection{Residual volatile fatty acid (VFA)}

Volatile fatty acid concentration is one of the most important parameter to indicate process stability during anaerobic digestion [30]. Accumulation of VFA is an indicator of a 
kinetic uncoupling between acid producers and consumers (e.g. acetic acid vs. propionic/butyric acid) and is typical for stress conditions [30]. Figure 5a shows the VFA profile per unit mg-eqAceticacid $\mathrm{L}^{-1}$ at the end of batch assay. It can be noted that SHW had significantly higher residual VFA concentration than WS and CM (Figure 5b). The residual

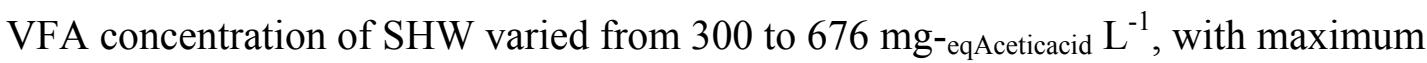
concentration examined when SSHW was treated with AUP. Meanwhile, residual VFA

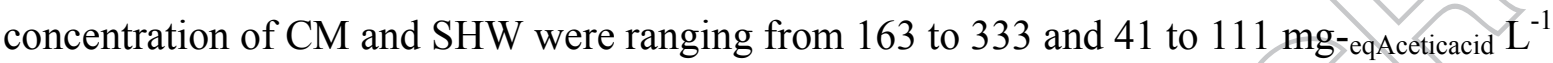
respectively.

Regardless substrate types, the influence of pre-treatments on residual VFA was not significant because of high variation in duplicates bottles. In all cases, residual VFA concentration was below the inhibition level reported in previous studies [31-32]. Acetic acid was the dominant fatty acid in all reactors and the amount of propionic and butyric acid were below $19 \mathrm{mg}$-eqAceticacid $\mathrm{L}^{-1}$ respectively. Propionate/acetate ratio was below the inhibitory limit $(<1.4)$ as suggested by previous studies [30,33], indicates the process was stable.

\subsection{Influence of substrate types on pre-treatment performance}

In this study, the characteristics of selected substrates significantly influence solubilisation ratio, anaerobic degradability, methane content, methane yield, and chemical compositions. It is noted that WS+PS and SHW are much easier to be digested compared to $\mathrm{CM}$, which corroborated to their nature characteristics. Cattle manure is a digested waste and mainly consisted of hardly degradable materials as the animals have taken up the easily digestible materials [34]. Cattle manure may also contain residues from the cattle food and bedding such as straw, sand and sawdust. These solids are either slowly degradable or not degradable [21]. Since WS and SSHW have never been digested before, single pre-treatment alone was sufficient to improve $A B$ and increased methane production. On the other hand, 
pre-treatments of SCM by AP and UP did not enhance overall methane yield rather increase methane production rate and shortened lag phase. The AUP may be an option for treating SCM if high-energy consumption due to ultrasonic system can be minimised.

\subsection{Energy balance}

Pre-treatment scalability is determined by the energetic and economic balance. Table 4 shows an energy input and output for each substrates with regards to pre-treatment methods. Surplus of energy was only observed when AP was applied to the substrates. It is because AP consumed low energy and boosts methane yield more than UP and AUP. Energy input prior to AP was around $0.4 \mathrm{MJ} \mathrm{kg}^{-1}$ vs and additional methane from WS+PS, CM and SHW were 119,14 and $134 \mathrm{~L} \mathrm{~kg}^{-1}$ vs, respectively. The positive energy gains calculated were ranging from 0.06 to $3.92 \mathrm{MJ} \mathrm{kg}^{-1} \mathrm{vs}{ }^{1}$. Ultrasonic and AUP were not profitable due to high energy consumption (30 to $36 \mathrm{MJ} \mathrm{kg}^{-1} \mathrm{vs}$ ) leading to negative energy balance.

Dhar et al. [35] reported that UP was economically feasible when specific energy input of $1000 \mathrm{~kJ} \mathrm{~kg}^{-1}$ TSS was applied on municipal waste activated sludge and the treatment was not profitable at higher specific energy input (5000 and $10000 \mathrm{~kJ} \mathrm{~kg}^{-1}$ TSS $)$ tested in the study. The observation supported the results examined in present study, as the energy consumed was over $50000 \mathrm{~kJ} \mathrm{~kg}^{-1}$ TS. However, the estimation of energy consumptions were probably overestimated as the calculations were based on laboratory scale conditions. As mentioned in Perez-Elvira et al. [10], laboratory ultrasonic systems are not efficient and often the specific energy required at laboratory scale is too high. It is noted that the energy supplied by ultrasonic equipment at full scale is much smaller than the laboratory devices, leading to positive energy budget [10].

In present study, the cost of AP was estimated by assuming the price of $\mathrm{KOH}$ in Denmark equals to $0.94 € \mathrm{~kg}^{-1} \mathrm{KOH}$ following Moset et al. [13]. The amount of $\mathrm{KOH}$ used for 
treating the substrates were ranging from 83 to $86 \mathrm{~g}_{\mathrm{KOH}} \mathrm{kg}^{-1} \mathrm{vs}$. It is calculated that the price of KOH used for AP of WS, SCM and SSHW were 81,80 and $78 € \mathrm{t}^{-1}$ vs, respectively. The selling price of methane from biogas in Denmark is equals to $0.67 € \mathrm{~m}^{-3} \mathrm{CH} 4$ [13], meaning an extra income of $89(\mathrm{WS}+\mathrm{PS}), 3(\mathrm{CM})$ and $54 € \mathrm{t}^{-1} \mathrm{vS}(\mathrm{SHW})$. Yet, it is noted that only AP of WS was profitable and the net profit was $8 € \mathrm{t}^{-1}$ vs. This net profit may be increased if the extra fertilizer value is considered in estimating the cost [13]. The fertilizer quality increase as $\mathrm{KOH}$ was added during anaerobic digestion, which will benefits the farmers, especially in the countries where potassium is imported [13]. Thus, it is expected that farmers will be willing to invest in potassium that returned with the digestate.

The price of $\mathrm{KOH}$ and cost of $\mathrm{KOH}$ production may yary depending on the countries, thus the economic calculation may be differ. For large scale application, alkali may be apply to the substrates by using spraying system, which consists of piston pump connected to a spray nozzle in a mixing chamber [13]. This method reduces the usage of water for chemical soaking and minimised the extra investment cost e.g. storage tank. Besides, the system is simple and suitable to treat large amount of substrates. Combining AP and wet storage is also another option to provide a cost-effective method for producing homogenous delignified biomass [36]. In this case, long reaction time required during AP is not a problem as the substrates normally stored for months before use for biogas production.

\section{CONCLUSIONS}

This study presents the influence of alkali, ultrasonic and, alkali-ultrasonic pre-

treatment on wheat straw, solid fraction of cattle manure and solid fraction of slaughterhouse waste to improve biogas production. Anaerobic digestibility of the substrates were improved regardless types of pre-treatment applied, which either increased overall methane production or enhanced methane production rate. Yet, alkali pre-treatment was the best method due to 
maximum extra methane yield and low energy consumption. Combination of alkali and ultrasonic may be an option for cattle manure, though further investigation is needed. Positive budget was only feasible when alkali pre-treatment was applied on wheat straw. At large scale, spraying system may be an option to reduce chemical usage, thus may minimize capital cost.

\section{ACKNOWLEDGEMENTS}

The first author expresses gratitude to Malaysian Government for the $\mathrm{PhD}$ scholarship. The authors wish to thank Laura Tey, Eva Romero, Laura Burgos and Eduard Muñoz at IRTA (Barcelona, Spain) for their assistance in the laboratory analysis. This work was supported by Idella Foundation, Innovation Fund Denmark and EUDP.

\section{REFERENCES}

[1] Holm-Nielsen JB, Seadi TAl, Oleskowicz-Popiel P. The future of anaerobic digestion and biogas utilization. Bioresour. Technol. 2009;100:5478-5484.

[2] Castrillón L, Fernández-Nava Y, Ormaechea P, et al. Optimization of biogas production from cattle manure by pre-treatment with ultrasound and co-digestion with crude glycerin. Bioresour. Technol.2011;102:7845-7849.

[3] Zheng Y, Zhao J, Xu F, et al. Pretreatment of lignocellulosic biomass for enhanced biogas production. Prog Energy Combust Sci. 2014;42(1):35-53. 
[4] Tabil L, Adapa P, Kashaninejad M. Biofuels Engineering Process Technology. New York (NY): McGraw-Hill; 2008. Chapter 18, Biomass feedstock pre-processing - Part 1: Pretreatment; p. 411-439.

[5] Velmurugan R, Muthukumar K. Ultrasound-assisted alkaline pretreatment of sugarcane bagasse for fermentable sugar production: optimization through response surface methodology. Bioresource Technol. 2012;112:293-299.

[6] Bruni E, Jensen AP, Angelidaki, I. Comparative study of mechanical, hydrothermal, chemical and enzymatic treatments of digested biofibers to improve biogas production. Bioresource Technol. 2010;101(22):8713-8717.

[7] Khanal SK, Grewell D, Sung S, et al. Ultrasound applications in wastewater Sludge Pretreatment: A Review. Crit. Rev. Environ. Sci. Technol. 2007;37:277-313.

[8] Bussemaker MJ, Zhang D. Effect of ultrasound on lignocellulosic biomass as a pretreatment for biorefinery and biofuel applications. Ind Eng Chem Res. 2013;52(10):35633580.

[9] Zou S, Wang X, Chen Y, et al. Enhancement of biogas production in anaerobic codígestion by ultrasonic pretreatment. Energy Convers Manage. 2016;112:226-235.

[10] Perez-Elvira S, Fdz-Polanco M, Plaza FI, et al. Ultrasound pre-treatment for anaerobic digestion improvement. Water Sci Technol. 2009;60(6):1525-1532. 
[11] Iskalieva A, Yimmou BM, Gogate PR, et al. Cavitation assisted delignification of wheat straw: a review. Ultrason Sonochem. 2012;19:984-993.

[12] Subhedar PB, Gogate PR. Alkaline and ultrasound assisted alkaline pretreatment for intensification of delignification process from sustainable raw material. Ultrason. Sonochem. 2014;21:216-225.

[13] Moset V, Xavier C de AN, Feng L, et al. Combined low thermal alkali addition and mechanical pre-treatment to improve biogas yield from wheat straw. J. Clean. Prod. 2018;172:1391-1398.

[14] Moset V, Xavier C de AN, Møller HB. Optimization of methane yield by using straw briquettes- influence of additives and mold size. Ind. Crops Prod. 2015;74:925-932.

[15] Subhedar PB, Gogate PR. Intensification of enzymatic hydrolysis of lignocelluloses using ultrasound for efficient bioethanol production: A review. Ind. Eng. Chem. Res. 2013;52:11816-11828.

[16] Angelidaki I, Alves M, Bolzonella D, et al. Defining the biomethane potential (BMP) of solid organic wastes and energy crops: A proposed protocol for batch assays. Water Sci Technol. 2009;59(5):927-934.

[17] Rodriguez-Abalde A, Fernandez B, Silvestre G, et al. Effects of thermal pre-treatments on solid slaughterhouse waste methane potential. Waste Manage. 2011;31(7):1488-1493. 
[18] APHA. Standard Methods for the examination of water and wastewater. $21^{\text {th }}$ Ed.

Washington DC: In: Greenberg AE, Clesceri LS, Eaton AD,; 2005.

[19] Noguerol-Arias J, Rodríguez-Abalde A, Romero-Merino E, et al. Determination of chemical oxygen demand in heterogeneous solid or semisolid samples using a novel method combining solid dilutions as a preparation step followed by optimized closed reflux and colorimetric measurement. Anal Chem. 2012;84(13):5548-5555.

[20] Jackowiak D, Frigon JC, Ribeiro T, et al. Enhancing solubilisation and methane production kinetic of switchgrass by microwave pretreatment. Bioresource Technol. 2011;102(3):3535-3540.

[21] Rico JL, Garcia H, Rico C, et al. Characterisation of solid and liquid fractions of dairy manure with regard to their component distribution and methane production. Bioresource Technol. 2007;98(5):971-979.

[22] Li L, Chen C, Zhang R, et al. Pretreatment of corn stover for methane production with the combination of potassium hydroxide and calcium hydroxide. Energy Fuels.

2015;29(9):5841-5846.

[23] Liu X, Zicari SM, Liu G, et al. Pretreatment of wheat straw with potassium hydroxide for increasing enzymatic and microbial degradability. Bioresource Technol. 2015;185:150157. 
[24] Lo HM, Kurniawan TA, Sillanpää MET, et al. Modeling biogas production from organic fraction of MSW co-digested with MSWI ashes in anaerobic bioreactors. Bioresource Technol. 2010;101(16):6329-6335.

[25] Møller HB, Nielsen AM, Murto M, et al. Manure and energy crops for biogas production: Status and barriers. Copenhagen: Nordic Council Ministers; 2008. p. 1-51.

[26] Braguglia CM, Gianico A, Mininni G. Comparison between ozone and ultrasound disintegration on sludge anaerobic digestion. J Environ Manage. 2012;5 (SUPPL.):S139S143.

[27] Fernandez-Cegri V, De La Rubia MA, Raposo F, et al. Impact of ultrasonic pretreatment under different operational conditions on the mesophilic anaerobic digestion of sunflower oil cake in batch mode. Ultrason Sonochem. 2012;19(5):1003-1010.

[28] Passos F, Uggetti E, Carrère H, et al. Pretreatment of microalgae to improve biogas production: A review. Bioresource Technol. 2014;172:403-412.

[29] Frigon JC, Mehta P, Guiot SR. Impact of mechanical, chemical and enzymatic pretreatments on the methane yield from the anaerobic digestion of switchgrass. Biomass Bioenerg. 2012;36:1-11.

[30] Ahring BK, Sandberg M, Angelidaki I. Volatile fatty acids as indicators of process imbalance in anaerobic digesters. Appl Microbiol Biot. 1995;43:559-565. 
[31] Siegert I, Banks C. The effect of volatile fatty acid additions on the anaerobic digestion of cellulose and glucose in batch reactors. Process Biochem. 2005;40:3412-3418.

[32] Wang Y, Zhang Y, Wang J, et al. Effects of volatile fatty acid concentrations on methane yield and methanogenic bacteria. Biomass Bioenerg. 2009;33(5):848-853.

[33] Hill DT. A comprehensive dynamic model for animal waste methanogenesis. TASAE. $1982 ; 25: 1374-1380$.

[34] Triolo JM, Sommer SG, Møller HB, et al. A new algorithm to characterize biodegradability of biomass during anaerobic digestion: Influence of lignin concentration on methane production potential. Bioresource Technol. 2011;102(20):9395-9402.

[35] Dhar BR, Nakhla G, Ray MB. Techno-economic evaluation of ultrasound and thermal pretreatments for enhanced anaerobic digestion of municipal waste activated sludge. Waste Manage. 2012;32(3):542-549.

[36] Cui Z, Shi J, Wan C, et al. Comparison of alkaline- and fungi-assisted wet-storage of corn stover. Bioresource Technol. 2012;109:98-104. 


\section{FIGURES}

Figure 1. Scanning electron microscope (SEM) images of (a) WS, (b) SCM and (c) SSHW

Figure 2. Solubilisation ratio $(\% \mathrm{~S})$ of untreated and pre-treated (a) WS (b) CM and (c) SSHW Figure 3. (a) Methane content of the substrates and (b) statistical analysis using Tukey test

Figure 4: Methane profile of (a) WS + PS (b) CM and (c) SHW based on modified Gompertz model

Figure 5: (a) Volatile fatty acid concentration of the substrates and (b) statistical analysis using Tukey test 


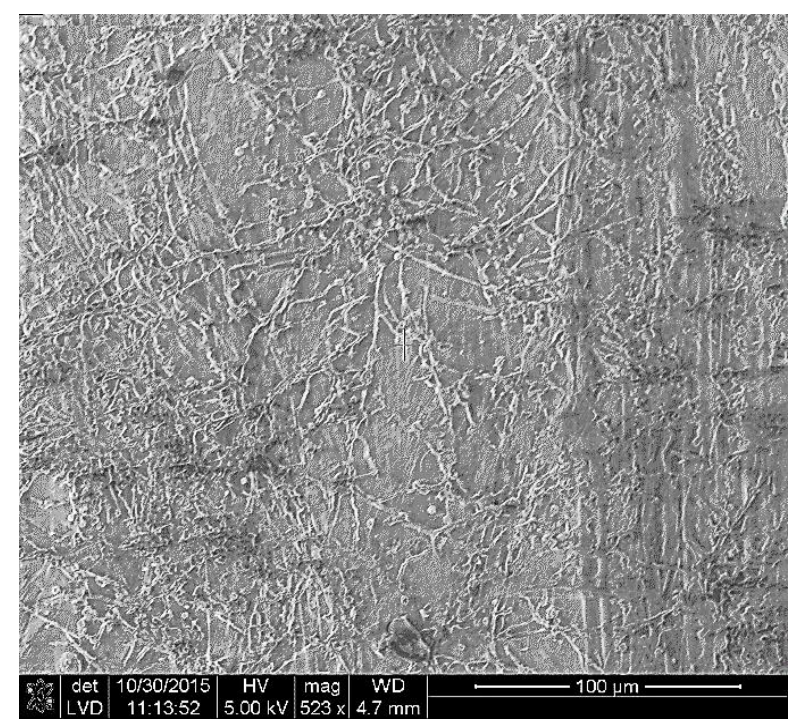

(a)

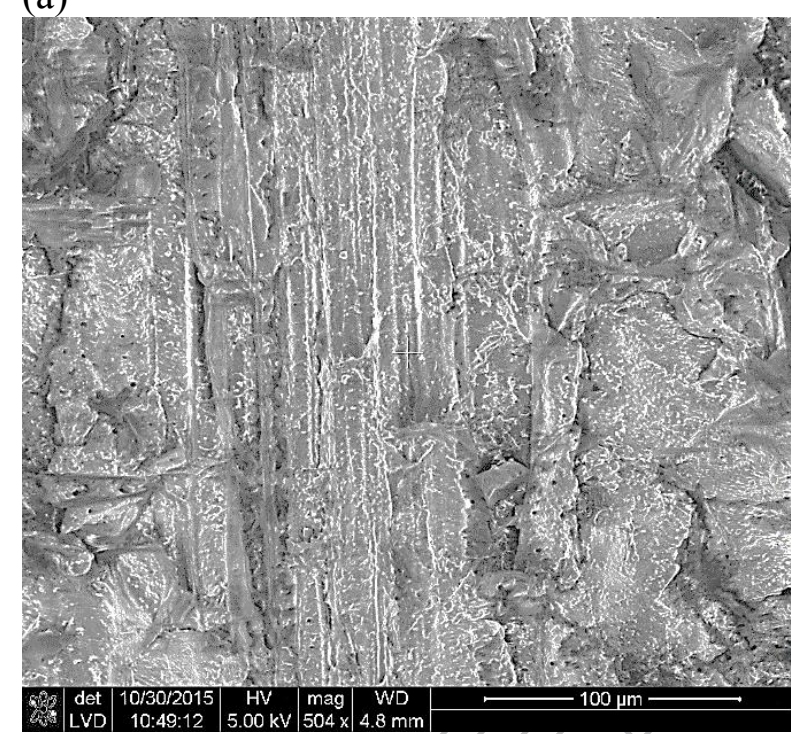

(b)

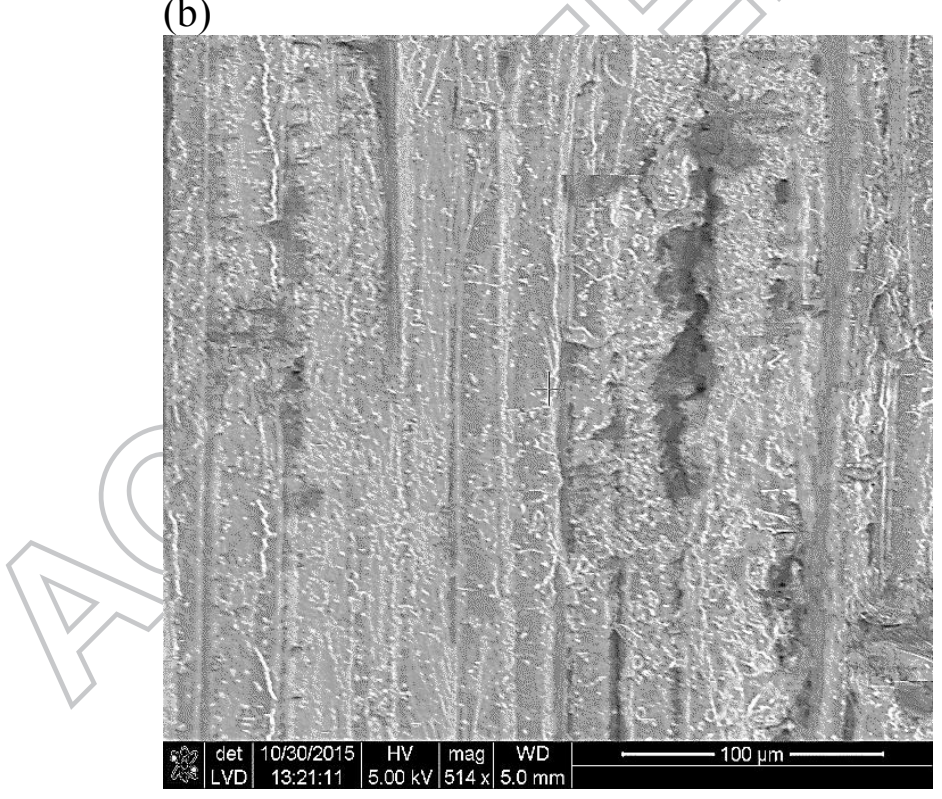

(c)

Figure 1 


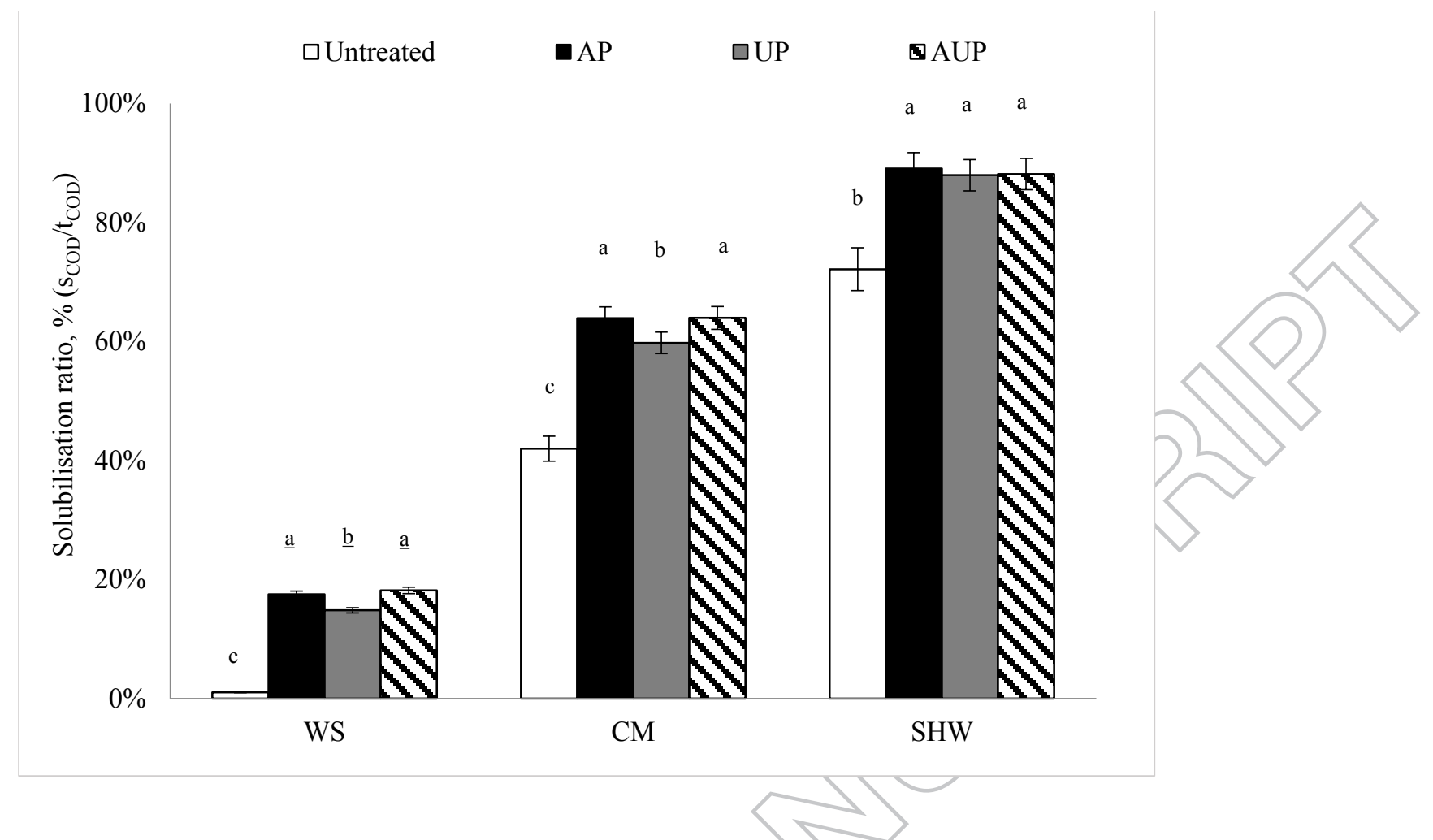

Mean values bearing different lowercase ( $a, b$ and $c$ ) are significantly different at $\mathrm{p}<0.05$ (Tukey test).

Figure 2 


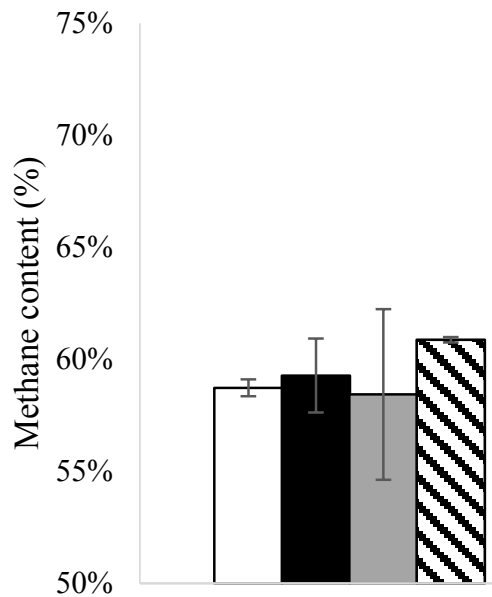

WS+PS

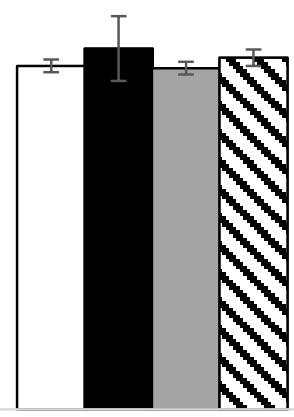

$\mathrm{CM}$

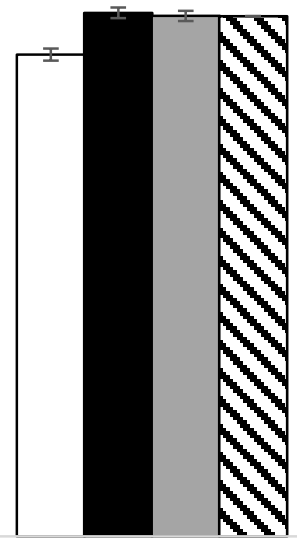

SHW

(a)

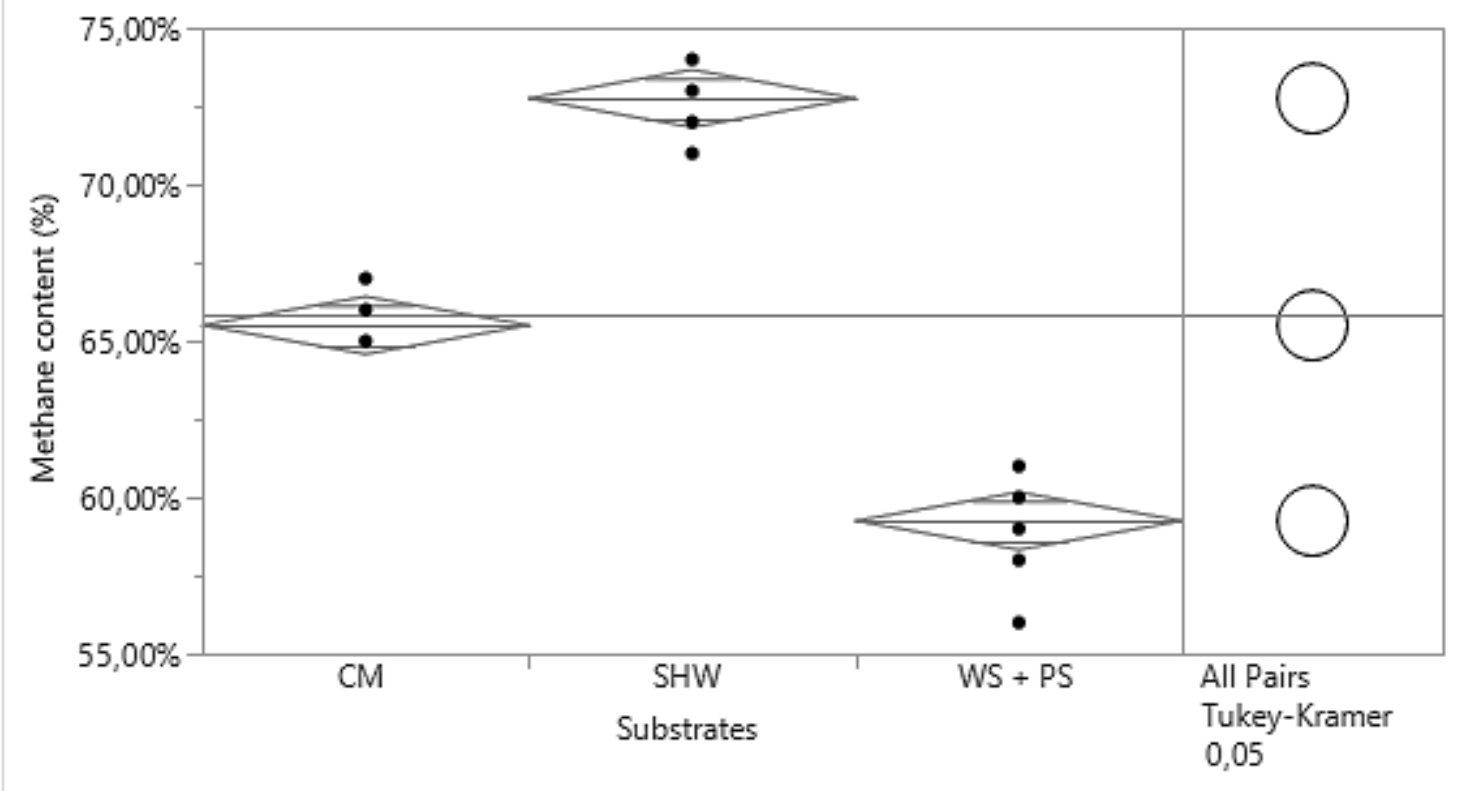

(b)

Figure 3 


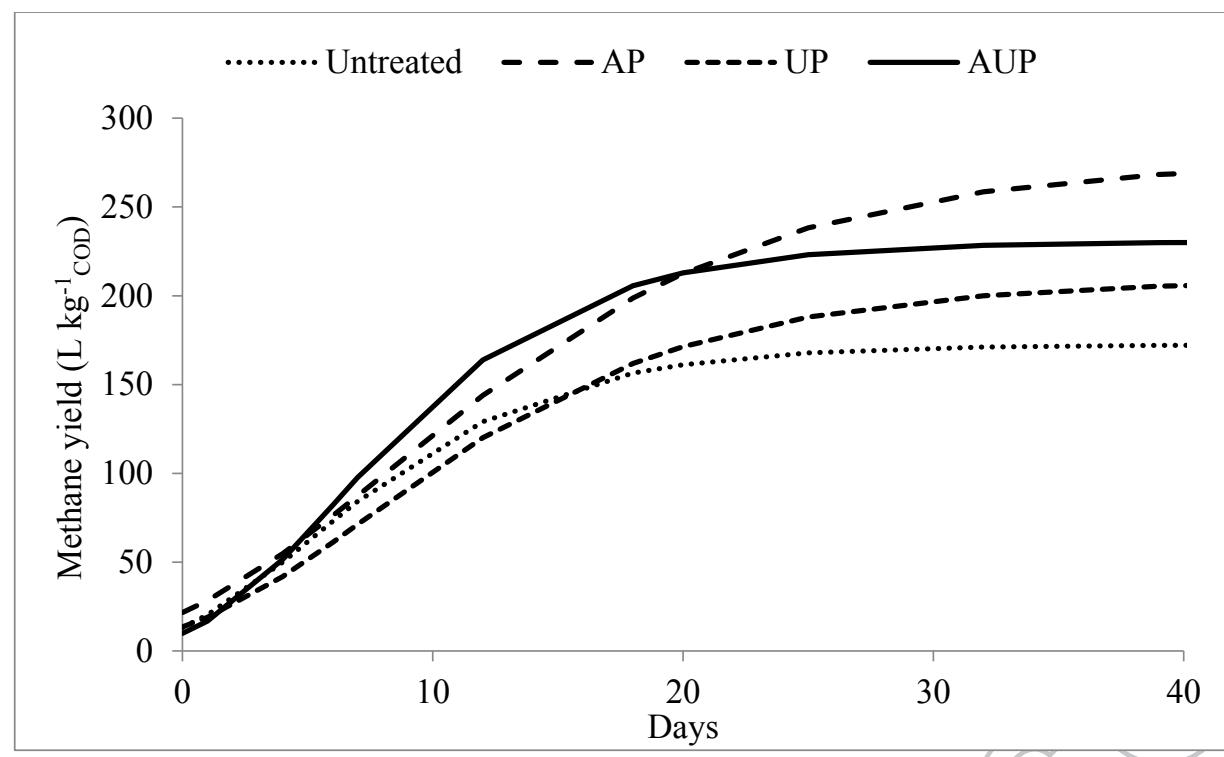

(a)

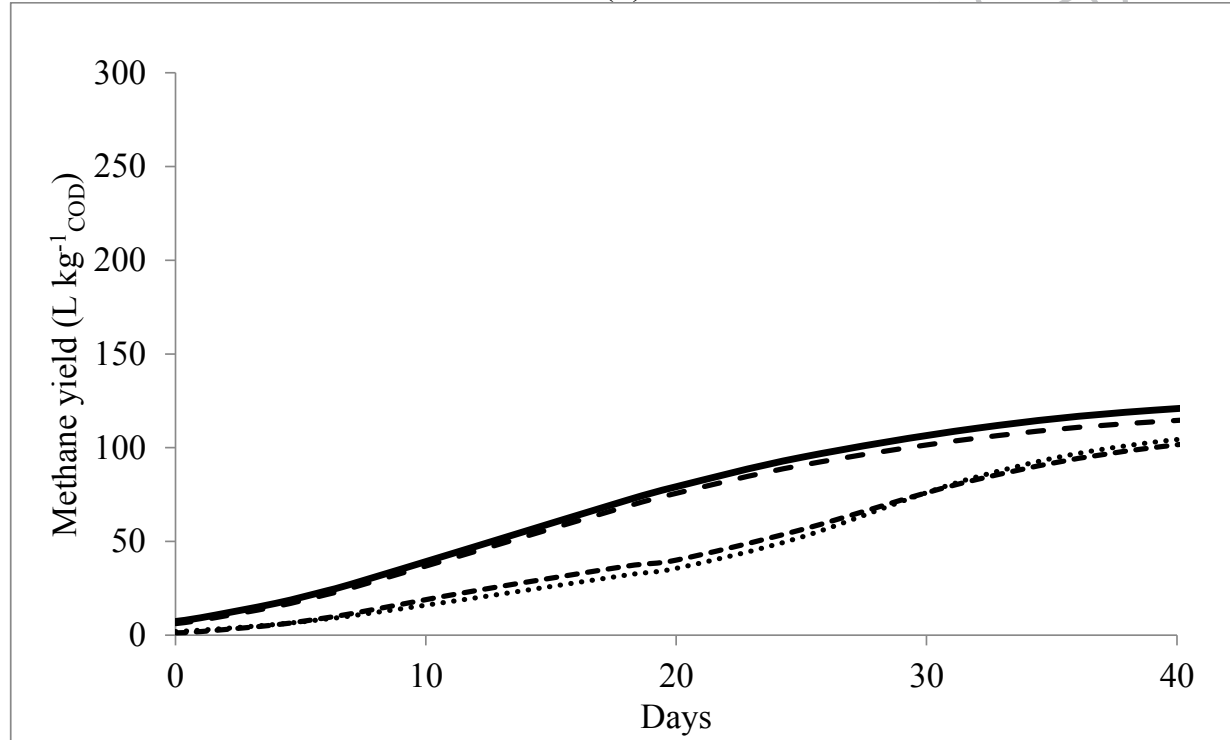

(b)

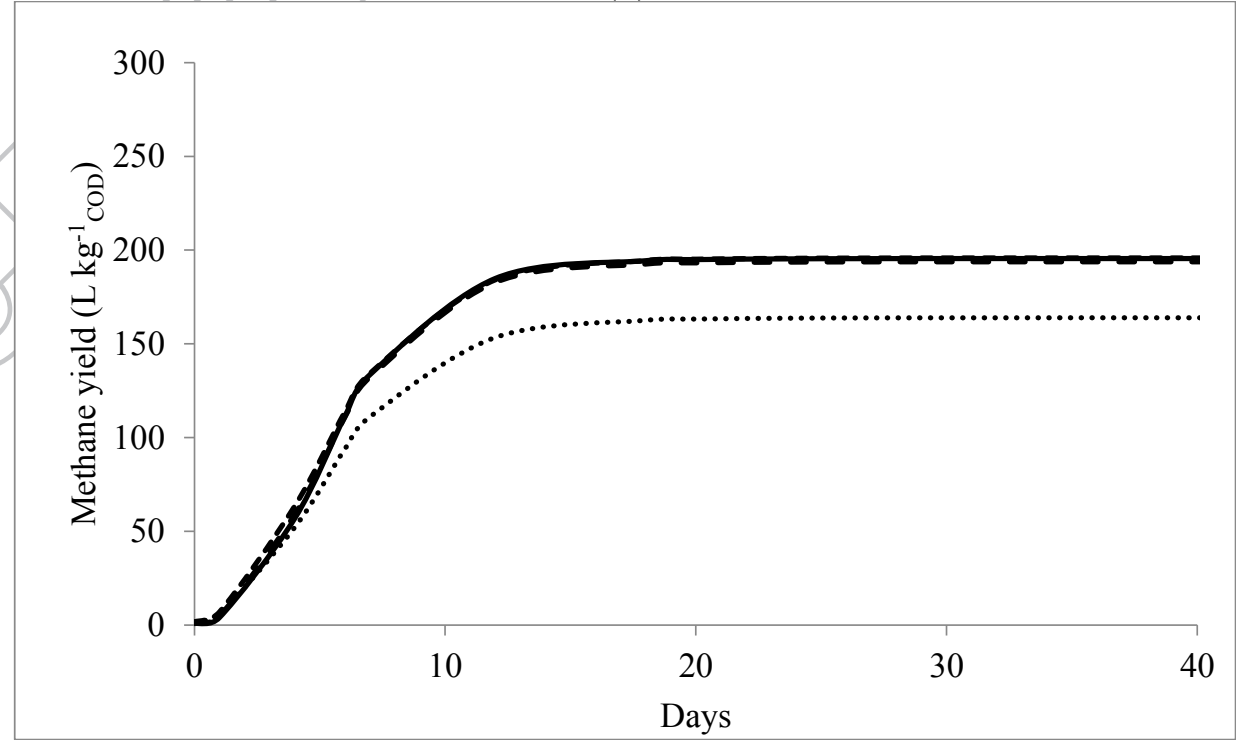

(c)

Figure 4 
-WS+PS $\square \mathrm{CM} \backsim$ SHW

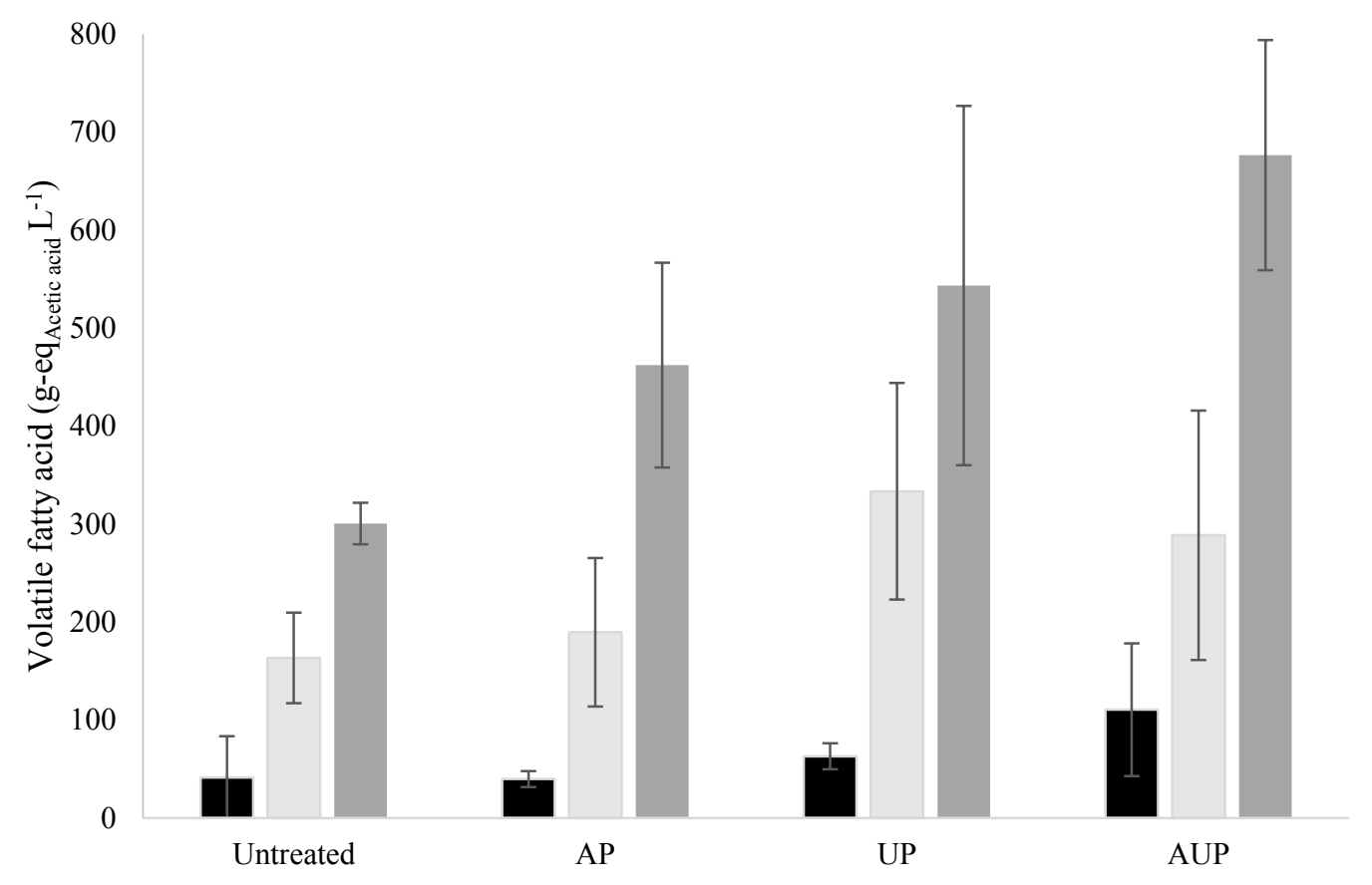

(a)

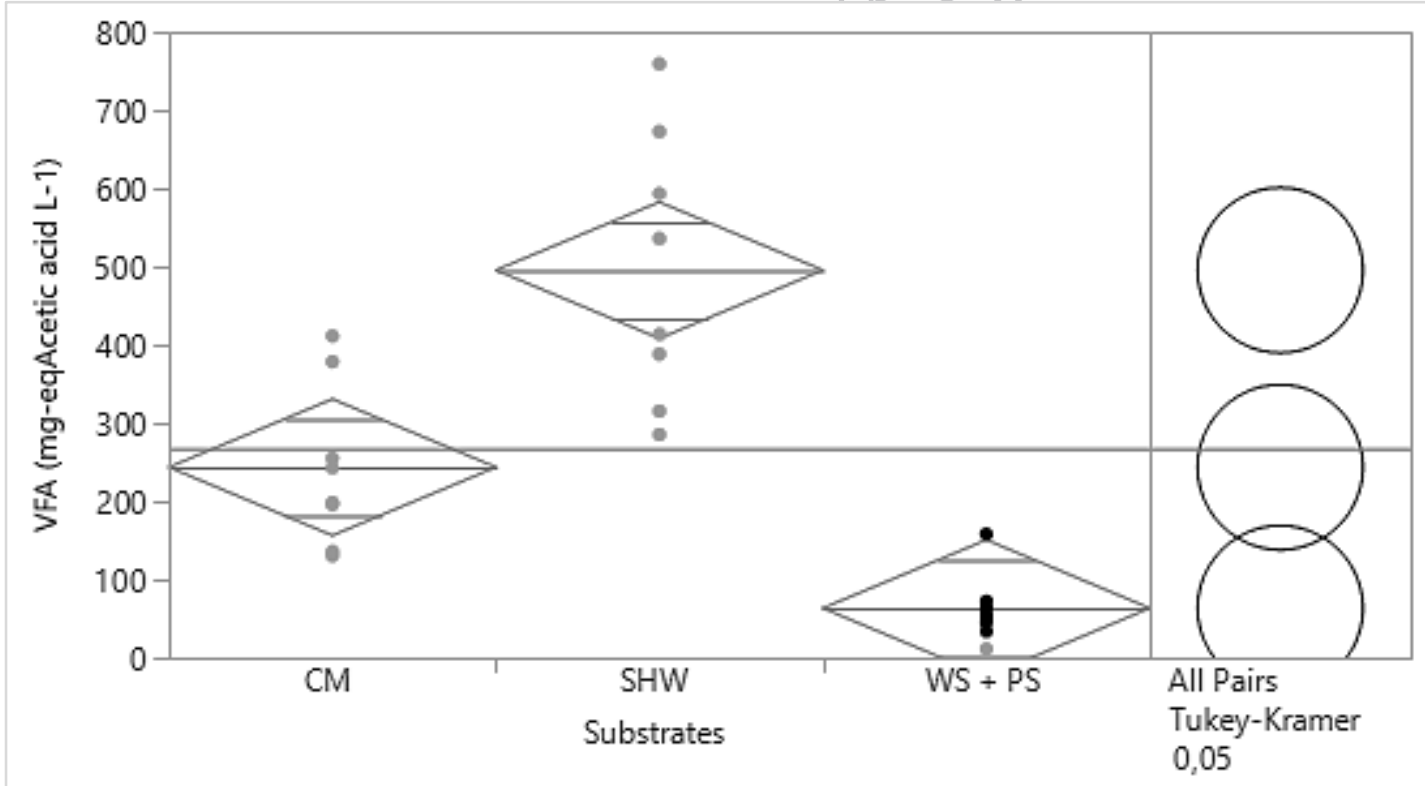

(b)

Figure 5 


\section{TABLES}

Table 1. Initial characteristics of untreated samples (solid and liquid fraction)

Table 2. Mathematical model parameters using Modified Gompertz

Table 3. Anaerobic biodegradability, $A B$ of substrates at different pre-treatments

Table 4. Energy profile of each substrates at different pre-treatments 
1 Table 1

\begin{tabular}{|c|c|c|c|c|c|c|c|c|c|c|}
\hline & $\mathrm{TS}, \mathrm{g} \mathrm{kg}^{-1}$ & $\mathrm{VS}, \mathrm{g} \mathrm{kg}^{-1}$ & VS/TS (\%) & $\mathrm{t}_{\mathrm{COD}}, \mathrm{g} \mathrm{kg}^{-1}$ & $\mathrm{C}(\%)$ & $\mathrm{H}(\%)$ & $\mathrm{N}(\%$ & $\mathrm{O}(\%)$ & $\mathrm{C} / \mathrm{N}$ & $\begin{array}{c}\text { Distribution } \\
(\% w w)\end{array}$ \\
\hline WS & $839 \pm 0$ & $783 \pm 0$ & 93 & $1097 \pm 5$ & 91 & 108 & & 52 & 46 & $50 \%$ \\
\hline PS & $14 \pm 0$ & $9.0 \pm 0$ & 63 & $12 \pm 5$ & - & & & - & - & $50 \%$ \\
\hline $\mathbf{W S}+\mathbf{P S}$ & 427 & 396 & 93 & 554 & - & & - & - & - & - \\
\hline CM_solid & $182 \pm 0$ & $172 \pm 0$ & 94 & $247 \pm 5$ & & 80 & 2 & 43 & 38 & $27 \%$ \\
\hline CM_liquid & $58 \pm 0$ & $41 \pm 0$ & 71 & $66 \pm 4$ & & & - & - & - & $73 \%$ \\
\hline $\mathbf{C M}$ & 91 & 76 & 84 & & & - & - & - & - & - \\
\hline SHW_solid & $224 \pm 1$ & $215 \pm 0$ & 96 & & 79 & 98 & 2 & 52 & 40 & $14 \%$ \\
\hline SHW_liquid & $69 \pm 0$ & $59 \pm 0$ & 0. & & - & - & - & - & - & $86 \%$ \\
\hline SHW & 90 & 80 & & 158 & - & - & - & - & - & - \\
\hline Inoculum & $2 \pm 0$ & $1 \pm 0$ & & $18 \pm 0$ & - & - & - & - & - & - \\
\hline
\end{tabular}

2 Nomenclature: WS - wheat straw, PS - pig slurry, CM - cattle manure, SHW- - slaughterhouse waste; ww - wet weight 


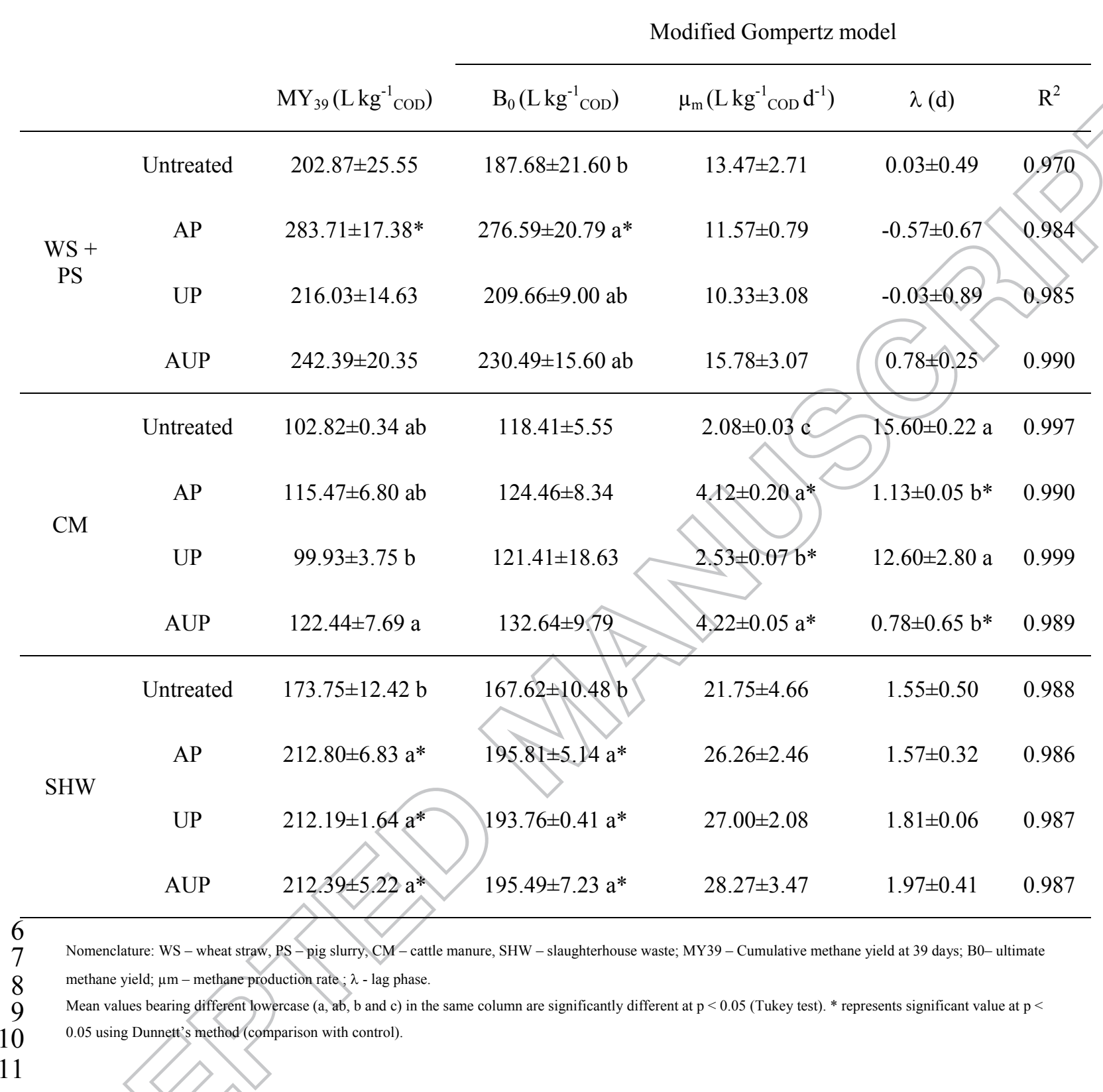


Table 3

\begin{tabular}{|c|c|c|c|c|c|}
\hline & & $M$ & $A$ & $X$ & $A B$ \\
\hline \multirow[t]{4}{*}{$\mathrm{WS}+\mathrm{PS}$} & Untreated & $53.54 \%$ & $1.21 \%$ & & $56.79 \% \mathrm{~b}$ \\
\hline & Alkali & $76.66 \%$ & $1.15 \%$ & $2.58 \%$ & $80.39 \% \mathrm{a}$ \\
\hline & Sonication & $58.68 \%$ & $1.34 \%$ & $2.09 \%$ & $62.10 \% \mathrm{ab}$ \\
\hline & AA-sonication & $65.68 \%$ & $1.86 \%$ & $2.43 \%$ & $69.97 \% \mathrm{ab}$ \\
\hline \multirow[t]{4}{*}{$\mathrm{CM}$} & Untreated & $29.38 \%$ & $4.09 \%$ & $1.88 \%$ & $35.34 \%$ \\
\hline & Alkali & $32.49 \%$ & $4.77 \%$ & $2.14 \%$ & $39.40 \%$ \\
\hline & Sonication & $28.56 \%$ & $8.59 \%$ & $2.95 \%$ & $35.81 \%$ \\
\hline & AA-sonication & $34.26 \%$ & $8.14 \%$ & $3.01 \%$ & $45.42 \%$ \\
\hline \multirow[t]{4}{*}{ SHW } & Untreated & $46.83 \%$ & $7.08 \%$ & $3.13 \%$ & $57.05 \% \mathrm{~b}$ \\
\hline & Alkali & $55.94 \%$ & & $4.72 \%$ & $73.14 \% \mathrm{a}$ \\
\hline & Sonication & $55.36 \%$ & $13.00 \%$ & $4.83 \%$ & $73.19 \% \mathrm{a}$ \\
\hline & AA-sonication & $55.85 \%$ & $16.00 \%$ & $5.58 \%$ & $77.40 \% \mathrm{a}$ \\
\hline
\end{tabular}

$A B$ is the percentage of anaerobic biodegradability at 39 days following modified Gompertz model; $M$ is the percentage of initial tCOD converted into methane at the end of the assay; $A$ is the percentage of initial tCOD converted into VFA at the end of the assay; $X$ is the percentage of tCOD employed in biomass generation.

Data presented represent an average of two measurements; mean values bearing different lowercase (a, ab and b) in the same column are significantly different at $\mathrm{p}<0.05$ (Tukey test). 
Table 4

\begin{tabular}{|c|c|c|c|c|c|c|}
\hline Pre-treatment & Samples ID & $\begin{array}{c}\text { Extra methane } \\
\left(\mathrm{Lkg}^{-1} \mathrm{VS}\right)^{*}\end{array}$ & $\begin{array}{c}\text { Energy Input } \\
\left(\mathrm{MJ} \mathrm{kg}^{-1} \mathrm{vs}\right)\end{array}$ & $\begin{array}{c}\text { Energy output } \\
\left(\mathrm{MJ} \mathrm{kg}^{-1} \mathrm{vs}\right)\end{array}$ & $\begin{array}{c}\text { Ratio } \\
\left(\mathrm{E}_{\text {out }} / \mathrm{E}_{\mathrm{in}}\right)\end{array}$ & $\begin{array}{l}\text { Net energy gain } \\
\left(\mathrm{MJ} \mathrm{kg}^{-1} \mathrm{vs}\right)\end{array}$ \\
\hline \multirow[t]{3}{*}{ AP } & $\mathrm{WS}+\mathrm{PS}$ & 119.23 & 0.42 & 3.84 & & 3.43 \\
\hline & $\mathrm{CM}$ & 14.44 & 0.41 & 0.47 & 1.14 & 0.06 \\
\hline & SHW & 134.21 & 0.40 & 4.32 & 10.80 & 3.92 \\
\hline \multirow[t]{3}{*}{ UP } & $\mathrm{WS}+\mathrm{PS}$ & 29.45 & 30.63 & 0.95 & 0.03 & -29.68 \\
\hline & CM & 9.36 & 30.28 & 0.30 & 0.01 & -29.98 \\
\hline & SHW & 73.21 & 29.75 & 2.36 & 0.08 & -27.39 \\
\hline \multirow[t]{3}{*}{ AUP } & $\mathrm{WS}+\mathrm{PS}$ & 49.80 & 32.14 & & 0.05 & -30.54 \\
\hline & $\mathrm{CM}$ & 12.34 & 34.02 & 0.40 & 0.01 & -33.62 \\
\hline & SHW & 82.50 & 35.99 & 2.66 & 0.07 & -33.33 \\
\hline
\end{tabular}

